\title{
THE INFLUENCE OF ACCOUNTABILITY, WORK EXPERIENCE AND PROFESSIONALISM ON THE QUALITY OF THE QUALITY OF THE WORK OF AUDITORS
}

\author{
Sihol Marito Simorangkir ${ }^{{ }^{*}}$, Jonathan Duberry Bukit ${ }^{2}$, Keumala Hayati ${ }^{3}$ \\ Prima University, Indonesia \\ maritosimorangkir15@gmail.com ${ }^{1^{*}}$, jonathanduberrybukit@gmail.com² \\ keumalahayatihakim@gmail.com ${ }^{3}$
}

\begin{abstract}
This research aims to examine the effect of accountability, work experience, and professionalism on the quality of auditor performance. Auditors are required to have high accountability because the auditor will present a financial report which must be accounted for by himself. In addition to having high accountability, auditors should also have good work experience so that auditors can convey a logical and logical understanding of what errors are contained in the financial statements. And also auditors need high professionalism so that auditors can carry out their duties professionally and well. The object of research is the auditors who are currently working at the BPKP office of North Sumatra. The data are 70 respondents. The sampling method is saturated sampling technique. Analysis of the data using validity, reliability and linear regression. And the results of the research prove that accountability has an influence on the quality of the work of auditors, while work experience and professionalism have no influence on the quality of the work of the audiences.
\end{abstract}

Keywords: Accountability, Work Experience, Professionalism, Auditor Quality

\section{INTRODUCTION}

Auditors who already have a lot of experience still cause errors, let alone be equated with auditors who have absolutely no experience. The deadline for an auditor to work is the most important thing that can affect the quality of the audit. From this explanation, previous research can conclude that through knowledge and experience the competence of auditors can be formed. (Goodman Hutabarat, 2012).

With experience, an auditor has a good knowledge of financial statements. so as to be able to provide logical opinion and clarity on frauds in the financial statements. Based on their responsibilities, they can increase the reliability in the financial statements of a company which not only has expertise but is also independent when auditing. (Goodman Hutbarat, 2012).

An auditor to perform duties as an audit is directed to have the ability to perform duties as an audit. To convince the auditor to give an opinion must be accompanied by sufficient evidence and review the suitability of the evidence, establish criteria according to applicable standards. (Trimanto, 2011)

(Hardiningsih and Oktaviani, 2012) Audit quality is the professional expertise of an auditor in carrying out his job. An auditor performs auditing tasks properly and correctly based on the complete stages in the audit process, and can provide the findings that have been obtained at the audit stage to determine good audit quality. (Indriyanti, 2013) said that an independent auditor can carry out an examination of the financial statements, with the auditor's opinion it will give good results.

The quality of auditors is also determined by several factors, among others, the first factor is accountability. Accountability is an obligation of accountability for the handling of trustworthy authority in order to achieve the planned objectives. Maintaining 
behavior, ethics, objectivity and responsibility are mandatory for public accountants to maintain their integrity. (Bawono and Singgih, 2010). Apart from accountability, work experience is a second factor. Work experience is the time a person works in carrying out their duties (Subhan, 2011). According to (Carolita, 2012) work experience is needed to realize the duties of an auditor at work. Apart from work experience, the third factor is professionalism. Professionalism is someone who has the ability to carry out tasks in their respective fields, carry out their profession by applying work guidelines related to predetermined work ethics. (Indonesian Institute of Certified Public Accountants, 2011) Research (William and Ketut, 2015) and (Nainggolan and Abdullah, 2016) say accountability has an influence on the quality of auditors' performance, but not for Research (Herlina and Murhaban, 2019) which says accountability has no influence on the quality of auditor performance. Restiyani (2014) explains that if experience gradually has a significant influence on the quality of the work of auditors, however, for research conducted by (Badjuri, 2011) explains that if experience has no effect on the quality of the work of auditors, Ernestina Dadiara (2019) said that professionalism does not has an influence on the quality of auditor performance, but not for Aminati (2014) and (Maulana, 2016) said that professionalism has an influence on the quality of auditor performance.

The following research is a combination of previous studies using the main variables to be observed. The variables of accountability, work experience, and professionalism in the quality of the work of auditors are put together in this study to re-examine whether they show consistency and inconsistency from previous research in the results of this study.
In the above discussion, the researcher is interested in doing research again to prove how much influence accountability, work experience, and professionalism have on the quality of auditor performance. From this, the study chose the title "The Effect of Accountability, Work Experience, and Professionalism on the Quality of Auditor's Work". Quality of auditors' work According to (Agusti et al, 2013) SPAP audit quality is declared to be of quality if the auditing guidelines and quality control guidelines can be met. Accountability is an ethical design that has concepts that a person has to be accountable for his obligations, and the expertise to provide answers to his environment. Accountability is seen from benchmarks and control for work (Ainia and Prayudiawan, 2011). Accountability has a duty to account for the success and failure of carrying out the goals of an organization. Work experience is formed by thinking, knowing and getting work done quickly. Work experience must require training for auditors so that skills and abilities are formed to solve problems that occur. The number of tasks that have been carried out by the auditors is shown by a lot of experience (Ismiyati, 2012). Professionalism as an auditor, to examine financial statements, professionalism is required. In carrying out their duties, auditors must be professional and responsible for completing their duties carefully. A professional attitude as an auditor should not make decisions arbitrarily without considering the risks that occur.

According to (Arens, Elder, \& M., 2011) Intelligence includes a reflection of completeness of audit documentation, sufficient evidence and completeness of audit reports. The dreamed auditor is always perfect but there are no careless actions and bad intention 
Hypothesis

On the basis of the provisions of the framework above, the following hypothesis is obtained:

$\mathrm{H}_{1}$ : Accountability affects Auditor Quality

$\mathrm{H}_{2}$ : Work experience affects the quality of auditors

$\mathrm{H}_{3}$ : Professionalism affects the Quality of the Auditor's Work

$\mathrm{H}_{4}$ : Accountability, work experience, professionalism as a whole affects the quality of the work of the auditors

\section{METHODS}

(Faisal, 2012) The research design used explanatory research, where the research described the influence between variables through hypothesis testing. This study aims to describe the correlation used in describing the influence of independent variables, including accountability, work experience, and professionalism on the dependent variable, namely the quality of the auditor's work.

The object is the North Sumatra BPKP Office. We distributed questionnaires totaling 126 respondents. A total of 70 questionnaires were received again. Where all the number of questionnaires received is again our research sample. The sampling technique used was saturated samples, because the entire population was sampled. Using primary data, because the data is obtained through questionnaires. The dependent variable is the quality of the auditor's work, then the independent variable is accountability. Work Experience and Professionalism.

\section{Data analysis method Valid Test}

The purpose of this test is to understand whether the questionnaire used can test the information needed. According to (Ghozali, 2011) the validity test method is the Pearsons product model correlation technique, which connects the indicator value of each variable with the total score.

\section{Reliability Test}

Testing aims to understand whether the questionnaire used is stable and can be trusted in measuring information. According to (Ghozali, 2011) the reliability test was carried out using the Alpha Cronbach approach.

\section{Classic Assumption Test}

Ghozali (2011) describes classical assumption testing, namely the initial stage before linear analysis. This test includes multicolonierity, heteroscedasticity and normality.

\section{Hypothesis Testing}

This research uses regression analysis. Using the following formula:

$$
Y=\alpha+\beta 1 X 1+\beta 2 X 2+B 3 X 3+e
$$

Information:

Y: Quality of auditors' work

$\alpha$ : Constant

$\beta$ : Regression coefficient

$X 1$ : Knowledge

X2: Accountability

X3: Professionalism

e: Error 
Table 1. Operational Definition

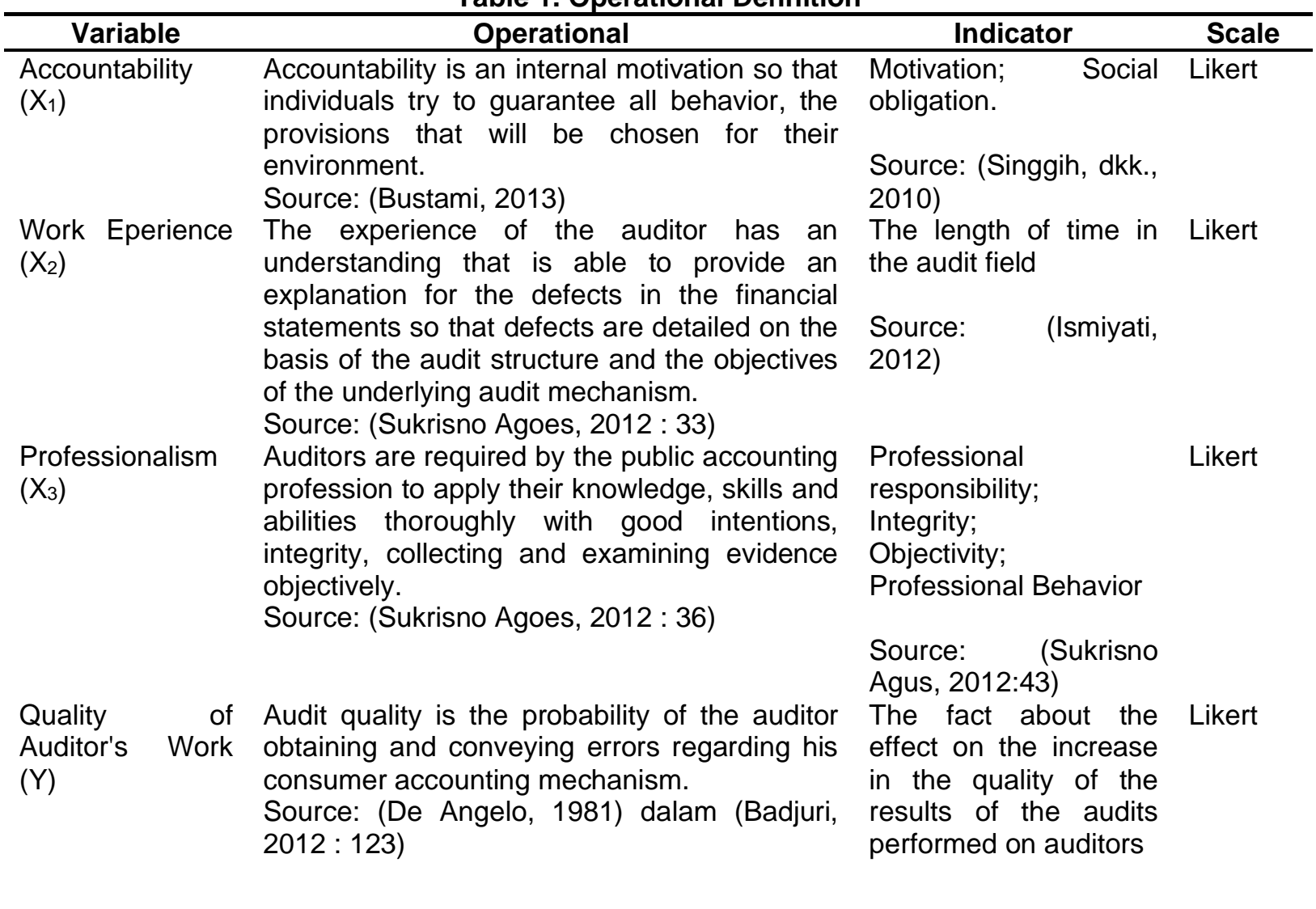

Source: (Silvia, 2015)

$\quad$ RESULTS AND RESEARCH
DISCUSSION $\begin{aligned} & \text { This research uses classical } \\ & \text { Results of Classical Assumption } \\ & \begin{array}{l}\text { Test } \\ \text { Normality test }\end{array}\end{aligned}$

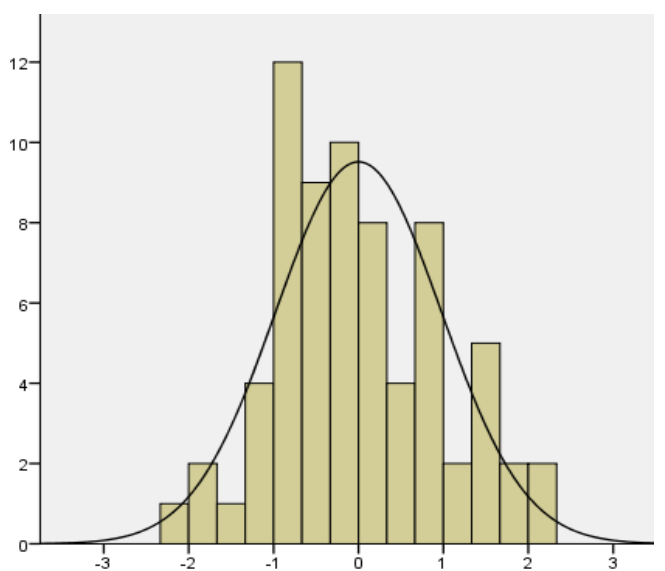

Figure 1. Histogram 
Judging from the histogram the line chart shows that the line adheres to the graph and does not move right or even left. That proves if the regression is suitable and normally distributed.

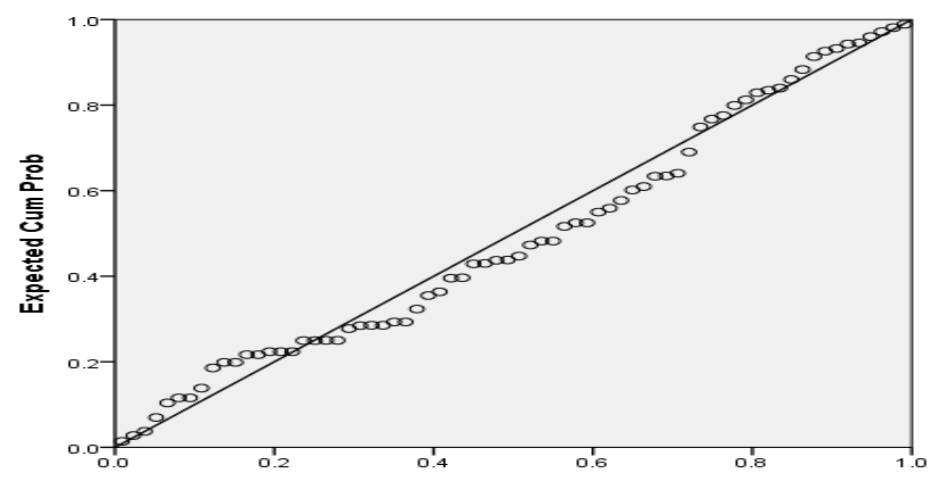

Figure 2. Normal P-Plot of Regression Standardized Residual

The picture of normality (Normal P-Plot of Standardized Regression) has scattered points in the diagonal line area, and is scattered according to the direction of the line, this shows that regression is feasible because it covers assumptions and is normally distributed.

Tabel 2. Kolmogorov

One-Sample Kolmogorov-Smirnov Test

\begin{tabular}{llr}
\hline & & \multicolumn{1}{c}{$\begin{array}{c}\text { Unstandardized } \\
\text { Residual }\end{array}$} \\
\hline Normal Parameters ${ }^{\text {a,b }}$ & Mean & 70 \\
& Std. Deviation & .0000000 \\
Most Extreme Differences & Absolute & 1.36671602 \\
& Positive & .083 \\
& Negative & .083 \\
Test Statistic & & -.066 \\
Asymp. Sig. (2-tailed) & .083 \\
\hline a. Test distribution is Normal. & $.200^{\mathrm{c}, \mathrm{d}}$ \\
b. Calculated from data. & \\
c. Lilliefors Significance Correction. & \\
d. This is a lower bound of the true significance. & \\
&
\end{tabular}

Source: Data Research Results, 2019

The value of Lilliefors

Significance Correction is 0.083 which is the Asymp value. Sig. (2-tailed) shows 0.200 . The conclusion of the test consideration results is $0.200>0.05$; so that the data is normally distributed. 


\section{Multicollinearity Test}

Table 3. Multicollinearity Test

\begin{tabular}{llrr}
\hline & & \multicolumn{2}{c}{ Collinearity Statistics } \\
Model & & Tolerance & VIF \\
\hline 1 & (Constant) & & \\
& ACCOUNTABILITY & .961 & 1.041 \\
& WORK EXPERIENCE & .897 & 1.115 \\
& PROFESSIONALISM & .920 & 1.087 \\
\hline
\end{tabular}

Source: Data Research Results, 2019

The Tolerance value of the variable $\mathrm{X} 1$ is $0.961 ; \mathrm{X} 2$ is 0.897 ; $\mathrm{X} 3$ is 0.920 . The VIF value of the $X 1$ variable is 1.041 ; $\mathrm{X} 2$ is 1.115 ; $\mathrm{X} 3$ is 1.087 . The tolerance value of the independent variables of this study is $>0.1$ and the VIF value is $<10$. In conclusion there is no multicollinearity.

\section{Heteroscedastity Test}

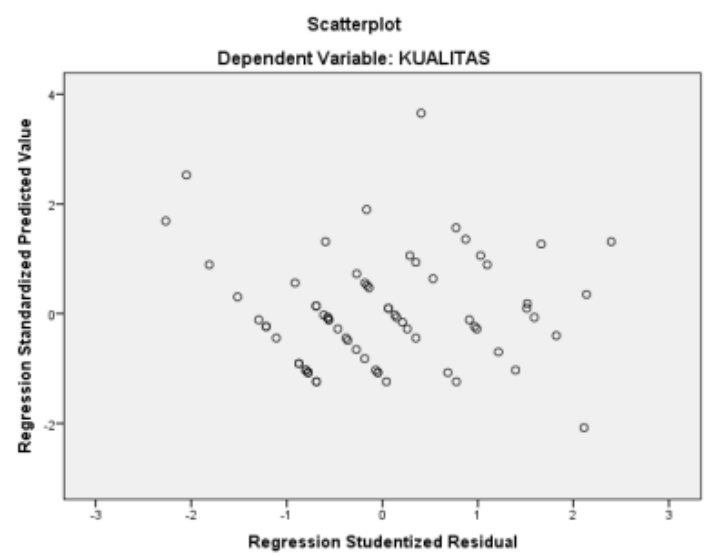

Figure 3. Scatterplot

It can be seen in the figure that the point distribution is irregularly above or below the 0 value on the $Y$ axis. So the conclusion is that there is no heteroscedasticity.

Table 4. Heteroscedastity Test

\begin{tabular}{llrr}
\hline \multicolumn{1}{c}{ Model } & T & \multicolumn{1}{c}{ Sig. } \\
\hline 1 & (Constant) & -.625 & .534 \\
ACCOUNTABILITY & 1.656 & .102 \\
WORK EXPERIENCE & -.411 & .683 \\
& PROFESSIONALISM & -.463 & .645 \\
\hline
\end{tabular}

Source: Data Research Results, 2019

The significance value of the variable $\mathrm{X} 1$ is $0.102 ; \mathrm{X} 2$ is 0.683 ; $\mathrm{X} 3$ is 0.645 . From this significant value, it is concluded that the results of this study are 0.05 ; then it is clear that there is no heteroscedastity problem. 
Regression Analysis Results

TABLE 5. Results of Regression Analysis

\begin{tabular}{llrr}
\hline & & \multicolumn{3}{c}{$\begin{array}{c}\text { Unstandardized Coefficients } \\
\text { Model }\end{array}$} & \begin{tabular}{c} 
Std. Error \\
\hline 1
\end{tabular} & (Constant) & 14.930 & 6.469 \\
& ACCOUNTABILITY & .578 & .150 \\
& WORK EXPERIENCE & .152 & .223 \\
& PROFESSIONALISM & .120 & .159 \\
\hline \multicolumn{4}{c}{ Source: Data Research Results, 2019 }
\end{tabular}

In the form of regression, the regression equation model that can be written is:

Quality of Auditor's Work $=14,390$ constant + (0.578) ACCOUNTABILITY $+(0.152)$ WORK EXPERIENCE + (0.120) PROFESSIONALISM

From the above explanation, information includes:

1. The constant value is 14,390 which means that the independent variables, namely knowledge, accountability, and professionalism are considered constant. Then the quality value of the results of the auditor's performance at the BPKP office in Medan City is 14,390 .

2. The regression coefficient on $X 1$ is 0.578 indicating an increase of $0.578 \%$ provided that the other independent variables remain.

3. The regression value on $\mathrm{X} 2$ is 0.152 indicating an increase of $0.0152 \%$ provided that the other independent variables remain.

4. The regression value on $X 3$ is 0.120 , indicating an increase of $0.120 \%$, which is the provision for other independent variables.

\section{Hypothesis Determination Coefficient}

Table 6. Hypothesis Coefficient Test Results

\begin{tabular}{lrrrrr}
\hline Model & R & & R Square & $\begin{array}{l}\text { Adjusted } \\
\text { Square }\end{array}$ & \multicolumn{2}{c}{$\begin{array}{l}\text { Std. Error of the } \\
\text { Estimate }\end{array}$} \\
\hline 1 & & $.469^{a}$ & .220 & .185 & 1.397 \\
\hline
\end{tabular}

Source: Data Research Results, 2019

The results of the table show the results of Adjusted $R^{2}$, namely 0.185 or $18.5 \%$, indicating that the audit quality variable explained the accountability, work experience, and professionalism variables was $18.5 \%$. Selebohnya $81.5 \%$ described other variables that were not observed in the study.

\section{Simultaneous Hypothesis Testing (Test F)}

\begin{tabular}{|c|c|c|c|}
\hline Model & & $\bar{F}$ & Sig. \\
\hline 1 & $\begin{array}{l}\text { Regression } \\
\text { Residual } \\
\text { Total }\end{array}$ & 6.211 & $.001^{b}$ \\
\hline
\end{tabular}

Based on the above results, the $F$ count is 6.211 and the $F$ table is in table (27.3) which is 2.99 , in essence $F$ count> F table (6.211> 2.99). So it can be concluded that accountability, work experience, and professionalism 
simultaneously have a positive impact in the BPKP office in Medan. on the quality of auditors' performance

\section{Partial Hypothesis Testing (t-test)}

\begin{tabular}{llcc}
\multicolumn{4}{c}{ Table 8. T-Test } \\
\hline Model & T & \multicolumn{2}{c}{ Sig. } \\
\hline 1 & (Constant) & 2.308 & .024 \\
& AKUNTABILITY & 3.851 & .000 \\
& WORK EXPERIENCE & .683 & .497 \\
& PROFESIONALISM & .759 & .451 \\
\hline \multicolumn{4}{c}{ Source: Data Processing Results, 2019 }
\end{tabular}

Source: Data Processing Results, 2019

Based on these results, partial test results were found, including:

1. In variable $X 1$, the significant value is $0.000<0.05$. The value of $t$ count $>t$ table $(3.851>2.056)$ so that $\mathrm{Ho}$ is rejected and $\mathrm{H} 1$ is accepted with the understanding that the accountability variable has a positive influence on the quality of auditors' performance in the BPKP Office of Medan City.

2. In the variable $X 2$ the significant number is $0.497>0.05$. The result of $t$ count $<\mathrm{t}$ table $(0.683<2.056)$ so that $\mathrm{Ho}$ is accepted and $\mathrm{H} 2$ is rejected with the understanding that the experience variable does not have a positive effect on the quality of the work of auditors at the BPKP Office of Medan City.

3 . In the variable $X 3$ the significant number is $0.451>0.05$ and the results of $t$ count $<\mathrm{t}$ table $(0.759<2.056)$ so that $\mathrm{Ho}$ is accepted and $\mathrm{H} 3$ is rejected with the understanding that the professionalism variable does not have a positive effect on the quality of auditors' performance in the BPKP Office of Medan City.

4. Accountability has an influence on the quality of the auditor's performance, while work experience and professionalism have no effect on the quality of the auditor's performance.

\section{Discussions}

The Effect of Accountability on the Quality of the Auditor's Work

From the table calculation, the accountability value $(\mathrm{X} 1)$ of $)=0.000$ $<0.05$ proves that accountability has an influence on the quality of the auditor's work. So that the conclusion is that $\mathrm{H} 1$ is accepted.

Research (Saripudin et al., 2012) in research (Tri, 2016) states that accountability has an influence on the quality performance of auditors at the BPKP Office of North Sumatra because each auditor has the thought of being accountable for the results of the auditors' examination work against the auditee. Agree with this research.

Research (Riski Setya Pratomo, 2015) states that accountability has no effect on the quality of auditors' work. Disagree for this research.

\section{The Effect of Work Experience on} the Quality of Auditor's Work

Based on the table calculation, the work experience (X2) is obtained, namely $\propto=0.497>0.05$, which states that work experience has no effect on the quality of auditor performance. So it can be concluded that $\mathrm{H} 2$ is rejected.

Research (Kovinna and Betri, 2014) in (Melody and Stefani, 2015) states that work experience does not have an influence on the quality of auditors' performance because auditors who have a lot of experience and a lot of experience do not necessarily guarantee that the audit quality of auditors is getting better. Agree with this research

Research (Silvia, 2015) and (Titin, 2016) say that work experience affects the quality of auditor performance. Do not agree with this research. 


\section{The Effect of Professionalism on the Quality of the Auditor's Work}

From the table calculation, the value of professionalism (X3) is obtained, namely $\propto=0.451>0.05$, which states that professionalism has no effect on the quality of the work of the auditors. Therefore, it is concluded that $\mathrm{H} 3$ is rejected.

There are characteristics that motivate an auditor to carry out his work based on his skills. The professionalism of an auditor at work can be seen from his good behavior and demeanor to do his job, namely presenting a quality audit report. In order for the audit report to be of quality the auditor must carry out all the stages of the audit that have been made. the more professional the auditor, the more qualified the audit will be.

Research (Futri and Juliarsa, 2014) in (Elisabeth, 2016) states that professionalism has no effect on the quality of auditors' performance because auditors do not necessarily obey professional standards in every audit assignment, so deviant behavior can be prevented. Agree with this research (Agusti and Pertiwi, 2013) said that the more professional the auditor, the better the quality of the audit he will get. Do not agree with this research.

\section{The Influence of Accountability, Work Experience and Professionalism on the Quality of Auditor's Work \\ After the regression coefficient} value is calculated, only accountability (X1) is positive. Stating that accountability has an influence on the quality of auditor performance. Meanwhile, the regression coefficient on Work Experience (X2) and Professionalism (X3) is negative. Prove that work experience and professionalism have no effect on the quality of auditor performance.

(Melody Iskandar and Stefani Lily, 2015) show that accountability has an influence on the quality of auditor performance, while experience has no effect on the quality of auditor performance. It is the same with research (Fietoria and Elisabeth Stefany, 2016) which states that accountability affects the quality of auditor performance, while professionalism has no effect on the quality of auditor performance.

\section{CONCLUSION}

This study aims to determine the effect of accountability, work experience, and professionalism on the quality of auditors' work. The object is the North Sumatra BPKP Office. From the results of multiple regression analysis tests carried out on the quality of auditor performance, the conclusion is that accountability has a positive effect on the quality of auditor performance, while work experience and professionalism have no effect on the quality of auditor performance.

\section{REFERENCES}

Akuntabilitas, P., Dan, K., \& Murhaban, H. (2019). Independensi Auditor Terhadap Kualitas Hasil Audit ( Studi Kasus Pada Inspektorat Kota Lhokseumawe ). 5, 31-40.

Ardiansyah, L. (2012). Public accountants are independent auditors that provide services to the general public, especially in the field of audit of financial statements made by his client. Under these conditions, the public accountant has an obligation to maintain the qualit. 1-11.

Badjuri, A., \& Kunci, K. (2011). FaktorFaktor Yang Berpengaruh Terhadap Kualitas Audit Auditor Independen Pada Kantor Akuntan Publik (Kap) Di Jawa Tengah Influencing Factors on Independent Auditors Towards Audit Quality in Public Accountant's Offices in Central Java. 3(2), 183-197.

Dharmawan, N. A. S. (2014). Pengaruh Tingkat Pendidikan Dan 
Pengalaman Pemeriksa Terhadap Kualitas Hasil Pemeriksaan (Studi Empiris Pada Kantor Inspektorat Kabupaten Klungkung Dan Karangasem). Jurnal IImiah Akuntansi Dan Humanika, 4 (1), 1450-1470.

Ekonomika, F., Bisnis, D. A. N., \& Diponegoro, U. (2013). Pengaruh Independensi, Pengalaman, Due Professional Care, Akuntabilitas, Kompleksitas Audit, Dan Time Budget Pressure Terhadap Kualitas Audit (Studi Empiris pada Auditor KAP di Jawa Tengah dan $D / Y)$. 786-798.

Etika, P., \& Dan, P. (2013). Pengaruh etika, profesionalisme dan pengalaman audit terhadap ketepatan pemberian opini akuntan publik.

Etika, P., \& Dan, P. A. (2016). Pengaruh

Etika,Independensi,Pengalaman Audit Dan Premature Sign Off Terhadap Kualitas Audit. Accounting Analysis Journal, 5(1), 1-7.

https://doi.org/10.15294/aaj.v5i1.9 756

Fietoria, \& Manalu, E. S. (2016). Pengaruh Profesionalisme, Independensi, Kompetensi dan Pengalaman Kerja Terhadap Kualitas Audit di Kantor Akuntan Publik Bandung. Journal of Accounting and Business Studies, 1(1), 20-38.

Hartono, R. (2019). Pengaruh Kompetensi, Independensi, Profesionalisme Terhadap Kualitas Audit. TEKUN: Jurnal Telaah Akuntansi Dan Bisnis, 8(1), 1-13. https://doi.org/10.22441/tekun.v8i1 .5528

Imansari, P., Halim, A., \& Wulandari, R. (2016). Pengaruh Kompetensi, Independensi, Pengalaman dan Etika Auditor terhadap Kualitas Audit (Studi Empiris Pada Auditor Kantor Akuntan Publik Di Kota Malang). Jurnal Riset Mahasiswa
Akuntansi Unikama, 4(1), 1-9.

Iskandar, S. L. I. M. (2015). Akuntabilitas Dan Kepuasan Kerja Terhadap Kualitas Audit. XVIII(2), $1-15$.

Kerja, P. P., \& Segah, B. (2018). Provinsi Kalimantan Tengah Effect Of Work Experience, Independence, Objectivity, And Motivation to Results of Auditor's Audit Quality from Inspectorate of Central Kalimantan. 17(2), 86-99.

Nurjanah, I. B., \& Kartika, A. (2016). Pengaruh Kompetensi, Independensi, Etika, Pengalaman Auditor, Skeptisme Profesional Auditor, Objektifitas dan Integritas Terhadap Kualitas Audit. Dinamika Akuntansi, Keuangan Dan Perbankan, 5(2), 123-135.

Pratomo, R. S. (2015). Pengaruh pengalaman kerja, independensi, objektifitas, integritas, kompetensi, dan etika auditor terhadap kualitas hasil audit. Jurnal Unpand, 113(2), 207-221.

Purba, F. K. (2013). Pengaruh Fee Audit Dan Pengalaman Auditor Eksternal Terhadap Kualitas Audit. Universitas Komputer Indonesia, $1-21$.

Suyanti, T., Halim, A., \& wulandari, retno. (2016). Pengaruh Profesionalisme, Pengalaman, Akuntabilitas dan Objektivitas Auditor Terhadap Kualitas Audit (Studi Empiris Pada KAP di Kota Malang). Jurnal Riset Mahasiswa Akuntansi Unikama, 4(1), 1-23.

Swasta, P., Bumn, D. A. N., \& Padang, D. I. (2019). Pengaruh kompetensi, profesionalisme, dan pengalaman kerja auditor terhadap kualitas audit internal pada perusahaan swasta dan bumn di padang. 1(4), 1828-1844.

Wardoyo, T. S., \& Seruni, P. A. (2011). Pengaruh Pengalaman dan Pertimbangan Profesional Auditor terhadap Kualitas Bahan Bukti Audit yang Dikumpulkan. Maksi, $6(2)$. 
JASa (Jurnal Akuntansi, Audit dan Sistem Informasi Akuntansi) Vol. 4 No. 3/ December 2020

ISSN 2550-0732 print / ISSN 2655-8319 online

Wiratama, W., \& Budiartha, K. (2015).

Professional Care Dan

Akuntabilitas Terhadap Kualitas

Audit. Pengaruh Independensi,

Pengalaman Kerja, Due

Professional Care Dan

Akuntabilitas Terhadap Kualitas

Audit, 1, 91-106. 